\title{
Cognitive perceptions of second language acquisition in Chinese undergraduate ESL/EFL students: A mixed methods approach
}

\author{
Robert Wayne Elliott, Di Zhang \\ Foreign Language School, Linyi University, China
}

\begin{tabular}{l} 
Article Info \\
\hline Article history: \\
Received Jul 11, 2019 \\
Revised Aug 15, 2019 \\
Accepted Aug 30, 2019 \\
\hline Keywords: \\
Chinese undergraduate students \\
Cognition \\
Contemporary strategies \\
ESL/EFL learning \\
Mixed methods
\end{tabular}

Corresponding Author:

\begin{abstract}
With the continued demand for teachers of English as a Second Language (ESL/EFL) in China, colleges and universities in China continue to struggle with teaching oral English to high volumes of undergraduate students using faculty-centered strategies. This concurrent mixed-methods, single-level, case study intends to examine Chinese undergraduate students' cognitive perceptions of their oral English ability as a segue to a more effective second language acquisition environment in a 21 st Century global education. The data analysis revealed three main themes intersected by the findings of the quantitative and qualitative analyses. The findings from this and future studies are intended to guide leaders, administrators, scholars, and students to affect national and provincial policy, school and classroom-based practices, and personal strategies to enhance students' ability to acquire their oral English skills.
\end{abstract}

Copyright $(0) 2019$ Institute of Advanced Engineering and Science. All rights reserved.

Robert Wayne Elliott,

Foreign Language School,

Linyi University,

Middle Shuangling Rd, Linyi, Shandong, China 276005.

Email: rbrt_lltt@yahoo.com

\section{INTRODUCTION}

Amidst the many challenges of China's education reform efforts in its test-dominated education system, the mandatory oral English learning in China continues to present major challenges for Chinese ESL/EFL students and their foreign teachers. Meanwhile, research with a focus on examining students' cognitive perceptions (their thinking about their own perceptions) of acquiring oral ESL/EFL abilities is sparse. Of equal importance is that foreign teachers arriving to teach ESL/EFL classes often find themselves ill-prepared in ill-equipped classrooms of a less than optimal classroom setting, left either with using outdated teaching materials or struggling to develop their own materials to use during courses of instruction without fully understanding students' thinking about their own perceptions of learning, much less with how they best acquire their second language learning. The purpose of this concurrent design, mixed methods case study is to reveal Chinese EFL/ESL undergraduate students' cognitive perceptions about various aspects of their oral English abilities at a four-year university in East China to make a holistic contribution to the body of literature for practice and future research.

While it would seem that China's Ministry of Education policies require all Chinese students to learn and master English as a foreign language since the 1970's, no stated policy could be found to confirm this [1], and thus the questions raised are: To what ends? Which one of the more than 100 English dialects? And, to what level of mastery? This leads to other questions of: How will students' achievement of this mastery be measured? And, is the tool used to measure this achievement valid and reliable? More importantly, how will teachers and students know they have really achieved mastery of the language? While 
this study does not attempt to answer these questions directly, it does attempt to inform scholars and practitioners on directions to take for future research and practice based on students' cognitive perceptions about their experience with acquiring their oral English skills. As a result of China's compulsory English language education that has been in place for more than four decades, it is estimated that a mere 50 million of the 1.3 billion Chinese in China are fluent in English-only 3.8 percent [1]. Let's take a closer look at the problem.

In the landscape of ESL/EFL practices, approaches to the development of students' oral English literacy as a second/foreign language remains extraordinarily problematic for students and their teachers in China for a number of reasons [2] and while researchers highlight the importance of the use of metacognitive inquiry (students' cognitive perceptions) as a means of improving ESL/EFL learning strategies as being vital to successful learning strategies for ESL/EFL students, relevant studies on the oral communication aspects are lacking [2-4, 6-9].

Taken from casual conversations with students over the past three years of teaching oral English classes at the case institution and with parents and children in the local community, most students in the sample are taught only English reading and writing in their formative (primary and secondary schools) years without much, if any, exposure to oral English until their first year of college. Moreover, students were taught mostly through lecture, recitation, and memorization techniques that focus on grammar-translation in overcrowded classrooms primarily for the purpose of passing the high school graduation examination (Gou Kou) for entering college. Admittedly, most students feel unprepared for the challenges they face as freshmen students taking their first oral English class at the University. Against the backdrop of using a combination of various teaching strategies that have proven to work well in EFL/ESL classes, understanding students' cognitive perceptions about ESL/EFL learning have helped guide teachers in their planning and implementation of these strategies to produce the most effective learning environment for students to acquire English as a foreign/second language [2-4, 6-9].

Although each strategy used is not so contemporary, thoughtfully planned and combined uses of them provide for a more an enhanced, engaging learning environment for students to achieve mastery of their oral English language skills through synchronous (classroom) and asynchronous (online) activities. The combined use of students' cognitive perceptions of their English learning and knowledge of proven contemporary strategies for teaching ESL/EFL students in other countries will make more efficient use of students' and teachers' time for the students to achieve the desired outcomes. While this study attempts to focus some on the strategies used, it will highlight primarily the findings of analyzing students' cognitive perceptions of Chinese undergraduate EFL/ESL students at the case institution in East China. Findings from this study are intended to inform ministry and school administrators, teachers and professors, and students about various implications of policy, the appropriateness and use of various teaching methods, and ways to improve student learning, respectively, which will contribute to the sparse body of mixed methods case study literature on this topic for continued investigation.

The review of scholarly literature revealed much insight into the myths, theories, and practices that are relevant to ESL/EFL teaching and learning relevant to Chinese students in China. While much literature exists to address topics that are variably related to the topic of this study, very few have a focus on the cognitive perceptions of undergraduate ESL/ESL students in China. Those that examine students' cognitive perceptions focus narrowly on the reading and writing aspects of second language learners, while others have a restricted focus on primary and secondary school students [3-8]. To address this review cogently, information is presented topically by relevance to this study.

Only in recent years has research on language and cognition begun to examine various aspects of bilingualism and multilingualism with much fervor, while focusing much attention on "how bilingual people and second language learners negotiate their lives in two languages" [11]. The works of prominent researchers such as Housen \& Simoens [10], Kroll [11], Harrington [12], Ellis [13], Krashen [14-16], Robertson \& Ford [17], and Yilmaz [18] reveal much insight into second language acquisition that serve to answer many relevant questions for gaining a better understanding of the issues and challenges involved with the cognitive aspects of acquiring a second language.

From the cognition and cognitive neuroscience perspectives, Kroll [11] does well in providing her in-depth coverage and analysis of the reviewed literature mostly from the adult L2 learner perspective while addressing: language processing; individual differences, contexts, and properties of second language learning; structural properties; technology, assessment, and third language learning; and some unresolved issues, barriers, and implications for cognitive research and practice.

Harrington [12] views second language acquisition as something where "competence develops in the mind of the learner" as a cognitive process and focuses his book chapter on second language sentence processing that involves "two approaches to understanding real-time sentence comprehension" as a cognitive process. In doing so, he addresses thoroughly the syntax- and constraint-based approaches to sentence

Cognitive perceptions of second language acquisition in chinese undergraduate ... (Robert Wayne Elliott) 
processing as two cognitive processing models for language processing and comprehension in L2 learners. He then closes by addressing the possible implications that research has on second language acquisition theory in terms of the relationship that each approach has on processing and learning, and the strengths and limitations of current sentence processing research methods being used. Knowledge of these implications are very useful when planning strategies for teaching and assessing L2 learners.

Ellis' [13] view of second language learning supports Yilmaz's [18] view by stating: “A fundamental tenet is that we learn language in much the same way as we learn everything else" and "the processes of learning are cut from the same cloth as the rest of human cognition". Also having strong ties to Harrington's work, Ellis [13] provides an overview of L2 acquisition in terms of its basic goals, methods, and constructs beginning with his thorough explanation of construction grammar which occurs through usage of the language to learn patterned sequences of words. As Kroll [11] infers in her work, Ellis [13] addresses language processing that allow "language users to be rational in the sense that their mental models of the way language works are the most optimal given their linguistic experience and usage to date" allowing the L2 learner to anticipate the linguistic constructions that are likely to be used in their continued discourse as a rational cognition operation. Ellis [13] continues by addressing the areas of exemplar-based abstraction and attraction (schematic constructions), emergent relations and patterns (developing adaptively), and the dialectic nature of second language acquisition that involves the L2 learner in a conscious conflict during language development.

In thinking about teaching and learning a second language as a foreign teacher teaching to undergraduate college students in his/her native country, we begin to realize that it involves creating an intercultural teacher-student relationship. As the authors [19] point out in their work, their exist dichotomies that capture the distinctiveness of intercultural communication that are at play during communication, so it would stand to reason that communications between a foreign teacher and his/her Chinese students would involve one or more of these dichotomies during their communication. These authors [19] posit six dialectics that involve intercultural communication: (a) cultural-individual; (b) personal-contextual; (c) differencessimilarities; (d) static-dynamic; (e) history/past-present/future; and (f) privilege-disadvantage.

As the authors [19] state, "we can better understand intercultural communication by examining [these] six dialectics". However, attempting to understand the dialectic nature of intercultural communication" goes against what [Westerners] are taught in [their] formal education," which makes it challenging because it requires thinking in "dualistic ways" simultaneously thus emphasizing contrasting concepts. While much of the literature focuses primarily on relationships of a personal or business nature, it does well to examine these approaches by viewing and understanding intercultural communication across a wide variety of cultures which may prove helpful during classroom teaching and learning.

Yilmaz [18] studied the cognitive perspective of learning as it applies to classroom practices to include her examination of underlying theories and practical classroom implications where she groups the types of learning theories into three domains of behaviorism, cognitivism, and constructivism, while providing clear explanations of the works done by Piaget, Vygostky, Bruner and others. While her [18] study does not focus specifically on language learning, she does well to outline and summarize each relevant theory and provides implications of using cognitive principles that apply directly to classroom teaching of most subjects.

In specific, Yilmaz [18] provides her explicitly detailed list of 11 strategies and principles to use and includes a list of 5 basic characteristics of cognitive theory-based classroom instruction that can be applied to language learning classrooms. She [18] then closes with details of her summarized list of 6 cognitive learning theory-based teaching methods, to include: "cognitive apprenticeship; reciprocal teaching; anchored instruction; inquiry learning; discovery learning; and problem-based learning" as the most prominent methods used, and gives detailed explanations and practical examples of how each can be applied to classroom practice.

Having extensive firsthand experience as a foreign expert teacher throughout many parts of China, Wolff [1] posits his "four great lies" in his extensive study involving 2,444 post-graduate students at two renowned universities in China in 2009. These four lies include: (a) you (every Chinese learner of English) must master English; (b) you can only make your English better by speaking with a native speaker; (c) Chinglish is no good; and (d) everyone in China needs to learn English. The results of his empirical study revealed these four lies impact directly and negatively "students in the areas of self-confidence, intrinsic motivation, self-discipline, creative thinking and autonomous learning skills". Instead of producing high functioning, literate graduates, many students find the bar set too high which "tends to discourage rather than motivate" students.

Liyanage, Bartlett, \& Tao [2] support Wolff"s conclusion by stating "the development of oral communication (listening and speaking) skills...for English as a Foreign Language (EFL) learners in mainland China has been a slow and cumbersome process for both learners and teachers," of which "most 
difficulties stem from lack of authentic contexts and purposes for oral language use" and culturally inappropriate pedagogy. Focusing on the three language learning behaviors (using translation to mediate meaning; focusing on grammar rules during oral English communication; and using context to assist comprehension, listening, and speaking oral English) examined in previous studies, the researchers shift their focus to examining three corresponding "cognitive strategies of translation, deduction, contextualization" to improve oral English learning.

In a review of the literature on language learning strategies, Zare [9] highlights what researchers defined as 14 "personal characteristics, styles, and learning strategies" of good language learners. In addition, the definitions and three classifications of learning strategies included in the review elicited main categories with some distinctive overlap, followed by an explanation of the factors that affect the choice of which strategies to use when teaching L2 learners. While this study does not address Chinese L2 learners specifically, the sources cited indicate the review addresses language learning on a global scale and encourages teachers to choose those learning strategies that are most appropriate for the students they are teaching.

Just as Wolff [1] mentions in his study, Liyanage, Bartlett, \& Tao [2] emphasize the importance of students passing high stakes examinations at the end of their secondary, postsecondary, and postgraduate levels. Using survey data from 1,440 undergraduate Chinese students completing the Language Learning Strategy Inventory (26 strategies listed), the researchers found significance when students used the three cognitive strategies when listening and speaking in class. These results indicate the possible success "to prepare students for oral communication beyond the classroom, and to prepare students to pass the listening test in the CET-4". More importantly, they indicate the need for classroom teaching strategies to be updated to 21 st Century methods for producing graduates that can "successfully negotiate the public examination system-as well as to interact with fellow citizens of a global society".

\section{RESEARCH METHOD}

This concurrent mixed methods case design study made use of a researcher-developed survey, and used Microsoft Excel 2010 to analyze the quantitative data (scaled data from students' responses to survey items 1-9) and the qualitative data (students' open-ended responses to survey item 10) that were hand-coded and analyzed. Three criteria were used to select the case study institution: (a) the type of undergraduate school and course of instruction; (b) proximity to the researcher's location; and (c) ease of access facilitated by a senior administrator. The research focused on students completing the undergraduate English Teaching and Business English Programs.

Because the use of contemporary teaching and learning strategies is a fairly recent phenomenon explored among universities in China "within its real-life context" and "the boundaries between phenomenon and context are not clearly evident" [20], use of the case study design was appropriate for this study [21, 22]. As further indicated by Yin [20], Merriam [21, 22], and Creswell \& Plano-Clark [23], a case study inquiry of an all-encompassing method that relies on collecting and analyzing multiple sources of evidence to draw conclusions that may or may not be generalizable to the broader population provides a more holistic view of the phenomenon being explored. Therefore, this study supplements the existing literature, and it may assist in refining data collection methods and criteria for sharpening the focus of future case studies, as Yin [20] suggests. The methods and results are presented as separate qualitative and quantitative inquiries, and then merged into a more holistic interpretation [25].

The participants in this study consisted of a sample of 162 of the 169 total undergraduate freshman Chinese Business English (33) and English Teaching (136) majors enrolled in Oral English throughout the 16-week spring 2018 semester meeting in the classroom 1 1/2 hours per week. All participants were taught identically with no variation in course content or methods used in each class.

This study used a 10-item researcher-developed survey containing nine multiple choice items using a five-point Likert scale, and one open-ended item for participants to provide comments about their thoughts that were related to any of the first nine items. The structure and contents of the survey followed the guidelines outlined by Alreck \& Settle [24]. To maintain anonymity of the participants, SurveyMonkey® was used to administer and collect the responses online from each participant. To test for validity and reliability, the survey was piloted to sophomore students who had completed both Oral English classes in their prior year (2017-18 academic year). Few corrections to the instrument were made, as necessary.

All currently enrolled Oral English course students were invited and encouraged to complete the researcher-constructed online survey anonymously, which was accessible via participants' mobile device or computer and takes approximately 5-10 minutes to complete. No incentives were offered for completing the survey. 
The quantitative data analyzed were the participants' multiple-choice responses to scaled items 1 through 9 in the completed survey to produce descriptive statistics and ANOVA results are displayed in tabular form in Table 1, Table 2 and Table 3.

The qualitative data analyzed were responses to the constructed-response item 10 in the completed survey to find common themes (categories) and sub-themes (sub-categories) are displayed in tabular form in Table 4. All comments were analyzed for word frequency and were coded to broad sub-themes (e.g., LSC = Lacks Self Confidence) and were then coded to overarching themes (e.g., Engagement and Opportunity).

Making use of a table created in a prior study to show the intersections of the quantitative and qualitative data under each identified overarching theme, the table was adapted to show the theme and subtheme codes derived in this study to locate where the quantitative themes and sub-themes intersect with the overarching themes. The table results provide a visual representation of these intersections to make further meaning of the results for their intended use (see Table 5).

\section{RESULTS AND DISCUSSION}

The quantitative analyses of responses to survey items 1-9 produced demographics, descriptive statistics, and response frequency results displayed in Table 1, Table 2 and Table 3, respectively.

Based on the data shown in Table 1, most students in each class were female as identified on the class rosters as being either male/female. The descriptive statistics shown in Table 2 reflect the average scaled responses (M), the standard deviation (SD) not exceeding 1.70, and significance (Sig) for each of the survey items (1-9). Table 3 shows the frequencies of responses to each of the first nine items which depict a clearer view of the responses than are displayed in Table 2. More precisely, Table 3 displays more clearly the two or three most frequent participant responses which indicate the number of students who think about ways to improve their oral English and responses about various aspects of their thinking.

The qualitative analyses of comments provided in survey item 10 produced qualitative themes (categories) and sub-themes (sub-categories) that are displayed in Table 4. Table 5 displays the merged quantitative and qualitative results from Tables 3 and 4 to show intersections with the overarching themes, as adapted from a prior mixed-methods study [25].

Because this study involves a sample from a single case institution, the findings are not generalizable to other institutions. However, sufficient information is provided to enable transferability in which the reader determines generalizability [23, 24]. Another limitation found during the early stages of this study was an issue with phone technology in China; some I-phones were unable to access the online survey while others experienced no issues. This, coupled with the slow connection speed of the only two providers in China, made it problematic for some students to complete the survey. This was delimited by recommending to participants they use someone else's I-phone or an Internet-capable computer.

Table 1. Demographics of Chinese undergraduate EFL students at the case institution

\begin{tabular}{cccc}
\hline Program Major & $\mathrm{n}$ & Male & Female \\
\hline Business English 1 & 33 & 5 & 28 \\
English Teaching 1 & 40 & 3 & 37 \\
English Teaching 2 & 39 & 4 & 35 \\
English Teaching 3 & 29 & 7 & 22 \\
English Teaching 4 & 28 & 7 & 21 \\
Totals & 169 & 26 & 143
\end{tabular}

Note 1: Survey participants were not asked to provide their demographic information Note 2: Students majoring in English Teaching are enrolled in the "Free Teacher" program.

Table 2. Descriptive statistics of survey responses from Chinese undergraduate EFL students

\begin{tabular}{ccccc}
\hline Variable & $\mathrm{n}$ & $\mathrm{M}$ & $\mathrm{SD}$ & $\mathrm{Sig}$ \\
\hline Time Thinking about Ways to Improve Oral English & 160 & 4 & 0.847 & 0.131 \\
Ways to Improve Oral English & 161 & 3.230 & 1.629 & 0.252 \\
Most Important Aspect of Improving Oral English & 161 & 1.876 & 1.166 & 0.180 \\
Primary Reason for Not Speaking in Class & 161 & 2.845 & 1.233 & 0.190 \\
Greatest Challenge to Improve Speaking in Class & 161 & 2.354 & 1.334 & 0.206 \\
Most Important Ways to Improve Oral English & 161 & 3.839 & 1.639 & 0.253 \\
Current Level of Oral English & 161 & 2.795 & 0.734 & 0.113 \\
Desired Level of Oral English & 161 & 4.497 & 0.681 & 0.105 \\
Satisfaction in Thinking and Talking with Others & 160 & 4.144 & 0.889 & 0.137 \\
About Ways to Improve Oral English & & & &
\end{tabular}


Table 3. Frequencies of quantitative survey responses from Chinese undergraduate efl students

\begin{tabular}{|c|c|c|c|}
\hline Variable & $\mathrm{n}$ & Most Frequent Responses Selected & Number of Responses \\
\hline Time Thinking about Ways to Improve Oral English & 160 & Sometimes; Often; Always & $68,53,35$ \\
\hline Ways to Improve Oral English & 161 & $\begin{array}{l}\text { All of the Above (e.g., study smarter, get } \\
\text { plenty of exercise, eat plenty of nutritious } \\
\text { food) }\end{array}$ & $71,67,20$ \\
\hline Most Important Aspect of Improving Oral English & 161 & Pronunciation; Vocabulary & 96,37 \\
\hline Primary Reason for Not Speaking in Class & 161 & $\begin{array}{l}\text { Don't know how to say what I want to say; } \\
\text { Lack self-confidence in OE ability; Don't } \\
\text { know what to say }\end{array}$ & $81,27,25$ \\
\hline Greatest Challenge to Improve Speaking in Class & 161 & $\begin{array}{l}\text { Little/no time to learn or practice; Low/no } \\
\text { motivation; Lack of direction from others }\end{array}$ & $58,41,30$ \\
\hline Most Important Ways to Improve Oral English & 161 & $\begin{array}{l}\text { Speak with a native English speaker; } \\
\text { Speaking by myself; Listening; Reading }\end{array}$ & $66,22,21,20$ \\
\hline Current Level of Oral English & 161 & Average; Below average & 98,39 \\
\hline Desired Level of Oral English & 161 & $\begin{array}{l}\text { Excellent (like a native English speaker); } \\
\text { Above average }\end{array}$ & 95,53 \\
\hline $\begin{array}{l}\text { Satisfaction in Thinking and Talking with Others } \\
\text { About Ways to Improve Oral English }\end{array}$ & 160 & $\begin{array}{l}\text { Helps a great deal; Helps much; Helps } \\
\text { Some }\end{array}$ & $66,59,29$ \\
\hline
\end{tabular}

Note: The values in the "Number of Responses" column is related to the responses in the "Most Frequent Responses Selected" column, respectively, from most to least frequent.

Table 4. Qualitative themes (categories) and sub-themes (sub-categories) from open-ended survey question responses

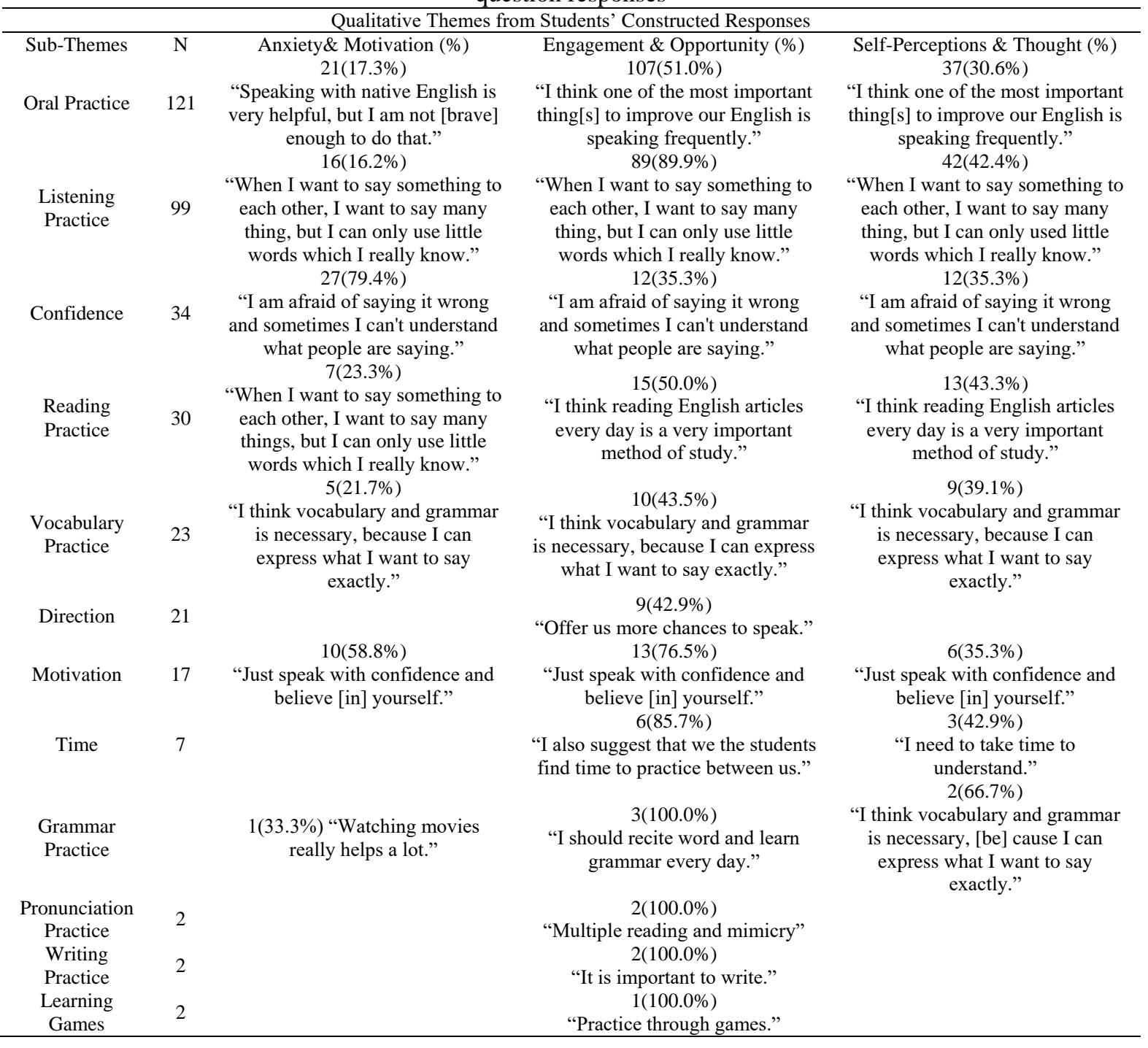


Table 5. Matrix of themes and sub-themes from qualitative and quantitative components.

\begin{tabular}{|c|c|c|c|}
\hline Overarching Themes & $\begin{array}{l}\text { Anxiety, } \\
\text { Confidence, and } \\
\text { Motivation } \\
\text { The importance of } \\
\text { students' self- } \\
\text { confidence in their } \\
\text { ability and their } \\
\text { motivation to } \\
\text { persist with } \\
\text { improving their oral } \\
\text { English abilities }\end{array}$ & $\begin{array}{l}\text { Engagement and } \\
\text { Opportunity } \\
\text { The need to provide } \\
\text { students with multiple } \\
\text { opportunities for } \\
\text { engaging them in } \\
\text { stimulating activities } \\
\text { that will stimulate the } \\
\text { learning experience } \\
\text { leading to improved oral } \\
\text { English abilities }\end{array}$ & $\begin{array}{l}\text { Self- } \\
\text { Perceptions } \\
\text { and Thought } \\
\text { Prompting } \\
\text { students to } \\
\text { engage in self- } \\
\text { reflection } \\
\text { about their } \\
\text { learning and } \\
\text { mastery of } \\
\text { oral English }\end{array}$ \\
\hline
\end{tabular}

Themes and Sub-Themes from Students' Constructed English abilities English abilities

Responses (Survey Item 10) (Qualitative)

Student comments about their 'Thinking About Learning English'

LSC (20) "I need more communication with the teacher, but lack courage." "And also, I feel a little nervous"

OP (88) Speak more, practice more. Everyday could have a topic to talk about. Find a partner to talk with. Listen to some radios or watch some English films more often. Use FIF as often as I can.

LP (72) I think listening to English radio and watching English movies and talk show can really help us a lot! I think in oral class, the teacher can speak slowly so I can understand and could know how to speak.

PP (1) Multiple reading and mimicry

RP (23) I think we should open our horizons to learn

English. For example, reading more and master more vocabulary.

GP (1) So I should recite word and learn grammar every day.

VP (9) For example, reading more and master more

vocabulary.

WP (1) It is important to write.

LD (10) In addition to the usual topic of interest, but also closer to our student life

LG (1) Practice through games.

LM (8) I want to have more motivation to learn English, but

I don't know how to do.

NET (2) I also suggest that we the students find time to practice between us.

Themes and Sub-Themes from Students' Survey Responses (Quantitative)

Students' Selected Responses to Survey Items

1. I sometimes spend time thinking about ways to improve my oral English

2. For me to improve my oral English, I must study smarter, get plenty of rest, eat and drink plenty of nutritious food, get plenty of exercise (all of the above)

3. I believe pronunciation is the most important aspect of oral English

4. The primary reason I choose not to speak in class is that $I$ don't know how to say what I want to say

5. The lack of time needed to learn and practicellow or no motivation is my greatest challenge that keeps me from improving my oral English

6. I find that speaking with a native English speaker is the best way to improve my oral English

7. My current level of oral English is average/below average

8. I anticipate my level of oral English to be excellent-like a native English speaker/above average

9. I believe spending time thinking and talking with others about ways to improve my oral English would help a great deal/help much

Note: Adapted from prior research conducted by Elliott \& Oliver [25].

Note: The "_-" indicates a theme (category), and the " $\mathrm{X}$ " a sub-theme that intersects with each overarching sub-theme (sub-category). 
The use of English only in the construction of the survey was another limitation to consider, which was delimited by using simple language and having selected students who were not in the sample population review the survey prior to its deployment. This allowed for any foreseeable problems to be resolved ahead of time. The final limitation was that of respondent bias due to cultural influence, as students and Asians, in their perception they should respond positively due to the possibility they may be identified and their responses may influence their final grade in the class. Moreover, it is not uncommon for Asian students to respond favorably to superiors, even if it means being dishonest in their responses on a survey. To help avoid this from happening, the survey instructions encouraged participants to be honest in their responses and told students their participation in the survey would have no effect on their grade in the class as their responses are completely anonymous. They were also not given any incentive for completing the survey.

One important assumption in this study involved participants' ability to read and understand all of the survey contents in English, and are able to communicate their qualitative thoughts in English completely and accurately in the open-ended item of the survey. As the subjects of this study are college freshmen continuing to study English as their first foreign language, their command of the English language is quite limited. However, all college freshmen acquire at least 10 years of learning written English and must pass the national college entrance exam to enter the university. Another assumption was that all students were able to access the survey online in China. Given the survey is hosted on a U.S. web site and China selectively blocks access to certain non-Chinese URLs (either partially or completely), it was uncertain whether some or all students would be able to access the survey using their Chinese-manufactured I-phones. While some students were successful in accessing and completing the survey, a few were not but used a computer or different phone to access and complete it successfully.

As one of the primary goals of this study, examining students' thinking and their perspectives about their journey to acquiring oral English as their first foreign language can bring about more thinking by students and their teachers about the possible tools and strategies that can certainly assist students with their acquisition of oral English skills and abilities. As such, teachers and students are encouraged to spend time in class thinking and dialoguing about what works well for them and what doesn't work well. Throughout the course of this study, students were exposed to WeChat social media and the FIF speech applications as tools for them to use outside of class to practice their oral English. They were also introduced to more contemporary methods of language teaching and learning that placed them at the center of their learning activities, as opposed to the more antiquated faculty-centered approaches they had been accustomed to prior to entering the university. Most often left to their own demise for what and how to study and practice, this brand-new experience was very foreign and uncomfortable to them until they realized they were in a safe environment that allowed them to make mistakes and learn from them. In addition, being given the opportunity to video-record their own oral English presentations on their own time outside of class instead of taking up valuable class time and having only one chance to do their best gave them more freedom and opportunities to practice their speaking ability as often as they wish to improve their oral English skills in a non-threatening environment.

One recommendation is to continue this study with semi-structured interviews individually or through focus groups with students from this sample to solicit deeper thinking and richer commentaries about their cognitive perceptions. One reason for this is the perceived inability of students in this sample to express themselves more completely and accurately in an online survey that they complete on their own. Semistructured interviews with topics created using the results of this study may help to facilitate/prompt participants to provide more thorough responses to each topic, thus providing more qualitative data to analyze and derive more pointed results. It is also recommended the findings in this study guide future studies that focus on teachers' cognitive perceptions of their teaching practices and the effects of these practices on students' cognitive perceptions about improving their acquisition of oral English. Much can be revealed by administering the survey containing the same questions reworded to ask what they believe their students would select as their response. Comparing the students' and teachers' responses would provide a more holistic view of the similarities and differences in thinking about their teaching and learning practices that would serve to guide teachers and students toward more effective ways to teach and learn oral English to acquire the language.

\section{CONCLUSION}

As stated at the beginning of this study, Chinese students are faced with a milieu of challenges in their pursuit of acquiring English as a second language. Similarly, EFL/ESL teachers experience their own share of difficulties as they too struggle to find the best ways to teach English to Chinese undergraduate students. As this study set out to reveal students' cognitive perceptions about improving their oral English skills, it became evident that focusing their attention on their perceptions and misperceptions revealed in this

Cognitive perceptions of second language acquisition in chinese undergraduate ... (Robert Wayne Elliott) 
study was worth talking about in their classes and thus served to aid them in their pursuit of acquiring their oral English goals.

While the results of this study are certainly informative and are intended to stimulate dialogues about the topic, the scope of this study is narrowly focused as intented and having students discuss their thoughts in class about its many aspects can foster deeper conversations about their thinking. And thus, these conversations can spark healthy debate which may prove to be constructive if managed properly. More importantly, the findings reveal root causes to the problems students face in their struggle to acquire the language and thus helps them to realize whether or not their perspectives about their journey to acquire the language are correct-most often, their own misperceptions about what works well.

Ultimately, the mix of quantitative and qualitative findings from this study are very informative, but merely scratch the surface as a new beginning to delve deeper into the minds of the students - to make stronger connections between theory and practice to enhance students' and teachers' risk-taking strategies and abilities for improving the EFL/ESL teaching-learning environment. However, the use of this mixed method strategy for case studies affords practitioners and researchers the ability to examine the challenges more holistically in their efforts to adapt their practice and research to respond to the challenges more completely and effectively.

\section{REFERENCES}

[1] Wolff, M., "The four great lies," in Of the Students, By the Students and For the Students, Chapter 1, 2010.

[2] Liyanage, I., Bartlett, B., \& Tao, T., "Cognitive strategies for dual imperatives: EFL listening and speaking in Chinese universities," Language Education in Asia, vol/issue: vol. 5(1), pp. 46-65, 2014.

[3] Zhang, L. J., "A dynamic metacognitive systems account of Chinese university students' knowledge about EFL reading," TESOL Quarterly, vol. 4(2), pp. 320-352, 2010.

[4] Chen, Y., "A cognitive linguistic approach to classroom English vocabulary instruction for EFL learners in mainland China," English Language Teaching, vol. 2(1), pp. 95-100, 2009.

[5] Doyle D., "Chagall guidelines \& teaching Chinese students: Theory into practice," 2005.

[6] Wang C.X., Calandra, B., Hibbard, S.T., McDowell Le Faiver M. L., "Learning effects of an experimental EFL program in Second Life," Education Tech Research Dev, vol. 60, pp. 943-961, 2012.

[7] Zhao C., Pandian, A., Singh, M. K. M., "Instructional strategies for developing critical thinking in EFL classrooms," English Language Teaching, vol. 9(10), pp. 14-21, 2016.

[8] Min-hsun, M. S. "A study of EFL technological and vocational college students' language learning strategies and their self-perceived English proficiency," Electronic Journal of Foreign Language Teaching, vol. 2(1), pp. 44-56, 2005.

[9] Zare P., "Language learning strategies among EFL/ESL learners: A review of literature," International Journal of Humanities and Social Science, vol. 2(5), pp. 162-169, 2012.

[10] Housen A., \& Simoens, H., "Introduction: Cognitive perspectives on difficulty and complexity in L2 acquisition," in Studies in Second Language Acquisition, vol. 38, pp. 163-175, 2018

[11] Kroll, J.F., "Adult second language acquisition: A cognitive science perspective," Book Chapter in Human Behavior in Military Contexts, 2008.

[12] Harrington, M., "Cognitive perspectives on second language acquisition," Book chapter in Robert B. Kaplan (Ed.), The Oxford Handbook of Applied Linguistics, New York: Oxford University Press, pp. 124-140, 2002.

[13] Ellis, N.C., "Cognitive perspectives on SLA: The associative-cognitive CREED*. AILA Review," vol. 19, pp. 100-121, 2006.

[14] Krashen S.D., "Second language acquisition and second language learning," Prentice-Hall Int'l, 1987.

[15] Krashen S.D., "Second language acquisition and second language learning," (Internet ed.), 2002.

[16] Krashen S.D., "Principles and practice in second language acquisition," (Internet ed.), 2009.

[17] Robertson K., \& Ford, K., "Language acquisition: An overview" LD online. 2008.

[18] Yilmaz K., "The cognitive perspective on learning: Its theoretical underpinnings and Implications for classroom practices," The Clearing House, vol. 84(5), pp. 204-212, 2011.

[19] Communication, "Communication in the real world: An introduction to communication studies," Minneapolis MN: University of Minnesota Libraries Publishing, 2016.

[20] Yin R. K., "Case study research: Design and methods," (3rd ed.). Thousand Oaks, CA: Sage, 2003.

[21] Merriam S. B., "Qualitative research and case study applications in education," San Francisco, CA: Jossey-Bass, 1998.

[22] Merriam S. B., "Qualitative research: A guide to design and implementation," San Francisco, CA: Jossey-Bass, 2009.

[23] Creswell J. W., \& Plano Clark, V. L., "Designing and conducting mixed methods research," Thousand Oaks, CA: Sage, 2007.

[24] Alreck P. L., \& Settle, R. B, "The survey research handbook," (3rd ed.). New York, NY: McGraw-Hill/Irwin Series in Marketing, 2004.

[25] Elliott, R. W., \& Oliver, D. E., "Linking faculty development to community college achievement: A mixed methods approach," Community College Journal of Research and Practice, 2015. 
